and degraded savage. He had advanced many stages beyond this when we first came into contact with him, and his life, though simple and rude, was on the whole well ordered and happy; and if his wants and aspirations were few, so were also his cares and worries."

The illustrations are numerous and very good; we are told on p. I39 that hammers are commonly regarded by the uninformed as pestles, "but this is an error," yet in the description of the accompanying plate they are described as "pestles" and "hammers." It is greatly to be regretted that the utility of this book is restricted by the extremely inadequate "bibliography" (sic). The author's valuable papers in the Reports of the British Association, especially for the years 1899,1900 , and I902, are not mentioned, neither does he give an exact reference to his own papers in the Journal of the Anthropological Institute. No clue is given where can be found, to take only two examples, Farrand's excellent paper on the basketry designs of the Salish Indians or the printed MS. of Mr. B. R. Ross. The single allusion to Prof. F. Boas is to his work on skull-deformation (reference again omitted), and the series of British Association Reports ending in 1898 is not even mentioned, although the twelfth and final report, with a good index, is of exceptional value. The important summary of Canadian ethnology in the Annual Archæological Report for I905 $_{5}$ (Toronto, I9o6) contains papers by the author on the coastal Salish, and by Father Morrice-on the Dénés, besides other valuable contributions by various authors, and as references are given to the literature the report serves as an admirable text-book on the anthropology of Canada. It is strange that no allusion is made to this publication; at all events, we recommend students who read Mr. Hill-Tout's book to consult the report in order to supplement his deficiencies.

\section{THE LEICESTER MEETING OF THE} BRITISH ASSOCIATION.

$\mathrm{THE}$ British Association is assured of a hearty welcome to Leicester for its seventy-seventh annual meeting to be held there from July $3 \mathrm{I}$ to August 7, under the presidency of Sir David Gill, K.C.B., F.R.S. Leicester is a place of great antiquity, few towns in England having a longer history of uninterrupted activity. Its Roman remains include the "Jewry Wall, a remarkable example of brickwork, and some mosaic pavement in situ. The geological features of the district are comprehensive, the Charnwood Forest, with its rocks providing many a geological puzzle, being within a few miles of the town. Botanists, too, have a happy hunting-ground there. The local committees and subcommittees are working hard to ensure the success of their efforts, and great interest is being shown on all sides in the visit of the association to Leicester. A guarantee fund of more than $3300 l$. has been raised towards the necessary expenses of the welcome, and this without any public appeal being made. No less than eleven amounts of rool. and upwards are included in this sum.

A call has been made on all the principal halls and public buildings throughout the town for general and sectional use, and it is believed that the arrangements when completed will be most satisfactory in every way. The greatest difficulty the executive have had to meet has been the fact that Leicester possesses no town hall or public building large enough for the purposes of the holding of the usual conversazione and general reception of the large number of members and guests anticipated. An ingenious suggestion, however, on the part of the chairman of the executive committee (Mr. Alfred Colson), which has met with the full approval of all concerned, promises to overcome all obstacles, and even to make the proposed conversazione additionally attractive on account of the unique way in which it will be housed. The intention is to utilise the whole of the present museum buildings, including the art gallery and mayoral reception rooms, for the use of which permission has been granted, and to erect on the four sides of the grass square adjoining a loggia or corridor constructed entirely of timber, 25 feet in width, forming a covered promenade about 500 feet in length. The four outer sides will be closed, but the inner sides, overlooking the grass plot, will be open, and so constructed as to be easily beautified with floral decorations. Internally the loggia will be draped with incombustible material and fitted with electric light and suitable furniture. Besides answering for the reception to be given by the Leicester Literary and Philosophical Society, the structure and grounds, with a military band in attendance, will make a convenient general rendezvous throughout the week.

A further edition of a very interesting work, "Glimpses of Ancient Leicester," by a local author, Mrs. Fielding Johnson, is being issued in connection with this meeting, and a handbook by another Leicester lady, Mrs. Nuttall, will be provided. The latter book will contain chapters on subiects of scientific interest prepared by various experts specially for the use of visitors.

Excursions are being arranged to many points of interest in the district, and the Mayor, Alderman Sir Edward Wood, I.P., will issue invitations to an evening fête in the Abbey Park. Sir Samuel Faire, J.P., will give a garden-party, and it may be taken for granted that the social side of the meeting will be well provided for. The comfort and enjoyment of all attending the meeting will not be overlooked, while the objects of the existence and visit of the association will throughout the week have the first consideration and thought.

\section{AN AËRONAUTICAL, EXHIBITION.}

THE well-arranged collection of balloon appliances and models of aëroplane systems organised by the Aëro Club in connection with the Motor-car Exhibition in London presented a striking contrast to the want of organisation in the aëronautical section of the Milan exhibition of last year. The large, almost empty room at Milan, with no attempt at systematic display except in connection with the exhibits of the Prussian Government Meteorological Station, has no counterpart in the present exhibition. Here everything was well displayed, and there was no lack of exhibitors and assistants ready to give information to any inquirer.

In studying the exhibits, I paid special attention to the aëroplane models, with the object of ascertaining how far they were likely to furnish material that would further the sistematic study of the problem of stability, and in particular of longitudinal stability, which is the more difficult of study. It appears, both from theory and experiment, that a very slight change in the form or dimensions, or even in the velocity of propulsion, of a model may change its motion from stable to unstable, and that if one machine travels safely through the air, another very closely resembling it may overturn at once. The general character of the exhibits does not seem to indicate that the constructors of flying models have NO. Y055, vOL. 757 